\title{
Empirical Study on Effect of Silicon Application on Rice Blast Disease and Plant Morphology in Indonesia
}

\author{
Adha Fatmah Siregar ${ }^{1,2}$, Husnain ${ }^{2}$, Kuniaki Sato ${ }^{1}$, Toshiyuki Wakatsuki ${ }^{1} \&$ Tsugiyuki Masunaga ${ }^{1}$ \\ ${ }^{1}$ Faculty of Life and Environmental Sciences, Shimane University, Matsue, Japan \\ ${ }^{2}$ Indonesian Soil Research Institute, Bogor, Indonesia \\ Correspondence: Tsugiyuki Masunaga, Faculty of Life and Environmental Science, Shimane University, Matsue, \\ Shimane 690-8504, Japan. Tel: 81-852-32-6066. E-mail: masunaga@life.shimane-u.ac.jp
}

Received: March 20, 2016 Accepted: April 27, 2016 Online Published: May 15, 2016

doi:10.5539/jas.v8n6p137 URL: http://dx.doi.org/10.5539/jas.v8n6p137

\begin{abstract}
Si fertilizer was never used in rice cultivation by farmers in Indonesia. To evaluate the effect of Si application on blast disease, plant morphologies, and stomata formation on rice plant, a field experiment was conducted in West Java, Indonesia. Two treatments, $\mathrm{Si}+$ (with $1000 \mathrm{~kg} \cdot \mathrm{ha}^{-1}$ of silica gel) and $\mathrm{Si}$ - (without $\mathrm{Si}$ application) were set in a randomized complete block design. The results showed that Si application in soil with high available Si 426 $\mathrm{mg} \mathrm{SiO} \mathrm{kg}^{-1}$ significantly reduce leaf $(\mathrm{p}<0.01)$ and neck $(\mathrm{p}<0.05)$ blast disease infection and increased stomata density $(\mathrm{p}<0.01)$. Si- had severer leaf blast infection than $\mathrm{Si}+$ which could reach up to score 4 and 5 . Si deposited on the tissue surface acts as a physical barrier by thickening the Si layer in cuticle which could decrease the number of blast lessions on leaf blades by limiting hypa penetration and invasion. Recently there was no report to prove whether Si deposition improves or changes the stomata density. The results confirmed that $\mathrm{Si}$ application have the potential of improving rice growth and yield through the increase of resistance to blast infection and increment in stomata density although they did not result in the yield increment in the present study.
\end{abstract}

Keywords: Si application, West Java, leaf blast, neck blast, stomata density

\section{Introduction}

Indonesia is a major producer of agricultural products in the world. The major food crops, ranked by area harvested are rice, corn, cassava, soybeans and peanuts (Ministry of Agriculture, 2015). Indonesia is known as the world's third-largest rice producer following China and India (FAO, 2015) and is also one of the world's biggest rice comsumers, indicating that rice is the most important food crop in Indonesia. Rice production is heavily concentrated on the islands of Java and Sumatera, with nearly $60 \%$ of total production emanating from Java island. At the same time, Java is the most densely populated island in the world and home to nearly $60 \%$ of the nation's population (approximately 143.8 million). In Indonesia, rice cultivation is rise up to three crop rotation per year with an average rice productivity of about 5.3 ton ha $\mathrm{a}^{-1}$. Mostly Indonesian farmers cultivate rice in lowland area which known as sawah. The term "sawah" in the present study refers to a leveled and bounded rice field with an inlet and an outlet for irrigation and drainage respectively (Wakatsuki et al., 1998). However, nowdays, known that the rice productivity in Indonesia has fluctuated and stagnated over the past decade (FAOSTAT 2005-2015). This situation might be because of several factors such as changes climatic factors and also the decline in soil fertility (Husnain, 2009). Declining crop yields are strongly related to soil quality degradation, particularly nutrient depletion (Roy et al., 2003). Apart from nutrient depletion, the occurrence of plant disease also plays a role on decreasing yield.

Beforehand due to the stagnated condition of rice yields, several cultivation methods have been adopted to improve rice production in Indonesia such as the extension of fertilizer, irrigation systems and also use high yielding rice varieties which are components of the green revolution technologies. The common fertilizers applied in Indonesia are nitrogen (Urea), phosphorous in form of triple super phosphate and super phosphate (SP-36), potassium $(\mathrm{KCl})$ and compound fertilizer containing $\mathrm{N}, \mathrm{P}$ and $\mathrm{K}$. However silicon ( $\mathrm{Si}$ ) application in rice production has not been appreciated in Indonesia because it was not considered as an essential nutrient. The non application of silica fertilizer on rice cultivation trigger the occurence of blast disease in rice plants. 
Silicon ( $\mathrm{Si}$ ) is the second most abundant element on earth, $26.8 \%$ by weight and is present in all mineral soils (Ingri, 1978; Iller, 1979; Faure, 1991; Klein \& Hurlburt, 1985). Kawaguchi and Kyuma (1977) reported that the soil-available Si content in tropical Asia rangedfrom 104 to $629 \mathrm{mg} \mathrm{SiO}_{2} \mathrm{~kg}^{-1}$. Si is not an essential element, but it has been proved to be beneficial elements for the growth and development of rice and sugarcane (Ma et al., 2006; Matichenkov \& Calvert, 2002; Epstein, 1999; Imaizumi \& Yoshida, 1958). Absorption of Si by crops is in the form of silicic acid which changes to irreversible amorphous silica. Therefore, availability of Si is very little as most sources of $\mathrm{Si}$ are insoluble and not available to crops (Epstein, 1994). Many species of wetland grasses, notably rice (Oryza sativa L.), accumulate $5 \% \mathrm{Si}$ or more in their leaf tissue. High concentrations of $\mathrm{Si}$ in rice plants enhance canopy photosynthesis, increased biotic and abiotic stress resistance, and contribute to healthy growth and high yield (Ma \& Takahashi, 2002).

Application of Si fertilizer is routine for rice or sugarcane in Japan, China, Brazil and other countries (Ma \& Takahashi, 2002; Korndorfer, 2001), while in Indonesia, Si fertilizer were never use in rice cultivation by farmers. This is as a result of limited research on soil available Si and its role in rice growth in Indonesia. Among the few research, report state that over the past three decades, soil Si availability has decreased by $11-20 \%$ (Darmawan et al., 2006) and dissolved Si (DSi) concentration in irrigation water in Indonesia has also decreased by $10-20 \%$ (Husnain et al., 2008). Kawaguchi (1966) and Miyake (1993) stated that Si depletion can occur in traditional rice soil from the continuous monoculture of high-yielding cultivars with intensive cultivation practice especially if farmers are nor replacing Si remove by rice uptake. In essence, decreasing rice productivity in Indonesia might be due to the depletion of available Si in the soil (Husnain et al., 2008). Husnain et al. (2011) stated that $76 \%$ from about 200 sawah sites studied in Sumatera and Java Islands, $76 \%$ of total 92 sites in West Sumatera, $22.5 \%$ of total 59 sites in West Java while in Central Java and East Java less than 3\% of total sites in both provinces were found to contain less than $300 \mathrm{mg} \mathrm{SiO}_{2} \mathrm{~kg}^{-1}$. This condition is reflected on the occurence of blast disease in Indonesian rice cultivation which might affect rice productivity. Rice blastcaused by the fungus Pyricularia grisea (Cooke) Sacc. [= Magnaporthe grisea (Hebert) Barr], is one of the most devastating diseases of rice plant. In Indonesia, this disease has been reported to cause severe damage to plant in many parts of the country. Hasanuddin (2004) stated that blast disease caused significant yield losses in area of 1,781, 1,084, 624, 395, and 200 ha in West Java, South Sumatera, North Sumatera, Central Kalimantan, and West Nusa Tenggara provinces, respectively. There is a tendency that the disease has become increasingly important,on account of the recent data indicating that 10,604 ha and 11,929 ha of rice field throughout the country were damaged by blast disease in 2010 and 2011, respectively (Wibowo, 2011). Up to the present, fungicides have been used effectively to control blast but not with Si application. In the present study, a field experiment was conducted to evaluate the effect of Si application on blast disease infection which greatly influence rice yield in Indonesia together with the effects of Si application on plant morphology including plant height, tiller numbers, and stomata formation were also evaluated.

\section{Materials and Methods}

\subsection{Sites and Soils}

Field experiment was conducted in farmer's field in Bojong Village, Sukabumi District, West Java province during the 2013 rainy season. Sukabumi district is one of endemic area for blast disease specialy neck blast. This location lies on $6^{\circ} 58^{\prime} 1.5^{\prime \prime} \mathrm{S}-106^{\circ} 49^{\prime} 30.4^{\prime \prime} \mathrm{E}$. Rice variety "Ciherang" was used which is common variety recommended by Ministry of Agriculture of Republic of Indonesia. Ciherang rice variety which was released in 2000 is an indica rice categorized as short-duration vaiety (116-120 days). It has an average yield of 6 ton ha ${ }^{-1}$ and is suitable for planting in rainy and dry season. This study consisted of two treatments, $\mathrm{Si}+$ (with $\mathrm{Si}$ application of $1000 \mathrm{~kg} \cdot \mathrm{ha}^{-1}$ of silica gel) and Si- (without Si application). We used a silica gel fertilizer "Super Inergy" imported from Japan. Randomized complete block design with 8 replications was used. The plot size was $3 \mathrm{~m} \times 3 \mathrm{~m}$ for each treatment. We installed plastic sheet on the treatments boarders from the soil depth of 30 $\mathrm{cm}$ to avoid contamination from surrounding plots. Each plots had an inlet and outlet for irrigation.

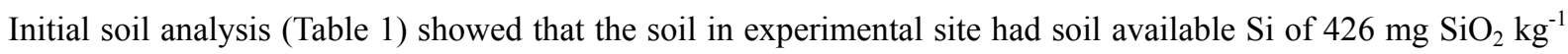
which is higher than critical level proposed by Sumida (1992) and Dobermann and Fairhurst (2000): 300 and 86 $\mathrm{mg} \mathrm{SiO} \mathrm{kg}^{-1}$ respectively.

The parent material of the study site is dominated by volcanic breccia, breccia andesitic-basaltic, locally agglomerate (Effendi et al., 1998). Andesitic-basaltic was known to contain 53-57 wt \% $\mathrm{SiO}_{2}$ (Le Maitre, 2005) which influenced of high soil Si available in this experimental site. 
Table 1. Initial soil analyses

\begin{tabular}{lll}
\hline Soil Properties & Values & Criteria \\
\hline $\mathrm{pH}\left(\mathrm{H}_{2} \mathrm{O}\right)$ & 5.57 & Slightly acid \\
$\mathrm{EC}\left(\mathrm{dSm}^{-1}\right)$ & 3.41 & \\
Total C $\left(\mathrm{gkg}^{-1}\right)$ & 21.63 & Moderate \\
Total N $\left(\mathrm{gkg}^{-1}\right)$ & 2.09 & Moderate \\
Exchangeable cations $\left(\mathrm{cmol}_{\mathrm{c}} \mathrm{kg}^{-1}\right)$ & & \\
$\mathrm{Ca}$ & 9.01 & Moderate \\
$\mathrm{K}$ & 0.21 & Low \\
$\mathrm{Mg}$ & 1.36 & Moderate \\
$\mathrm{Na}$ & 0.17 & Low \\
Available Si $\left(\mathrm{mg} \mathrm{SiO}_{2} \mathrm{~kg}^{-1}\right)$ & 426.54 & High \\
\hline
\end{tabular}

Note. *: Refered to Indonesian Soil Research Institute (2005); **: Refered to Sumida (1992).

\subsection{Plant Cultivation}

Land preparation was done by conventional tillage with two times plowing followed by leveling. Silica gel was applied before transplanting. Seedling from 21 days old nursery was transplanted into the puddled field with two seedlings per hill and row spacing of $25 \mathrm{~cm} \times 25 \mathrm{~cm}$. The fertilizer dosage was $300 \mathrm{~kg} \cdot \mathrm{ha}^{-1}$ of NPK compound fertilizer (15:15:15) and $50 \mathrm{~kg} \cdot \mathrm{ha}^{-1}$ for Urea. NPK compound fertilizer was applied in three times, at 7, 30 and 45 days after transplanting (DAT). Meanwhile, Urea was applied once time at 7 DAT. For seedling, $2 \mathrm{~kg}$ Urea and $10 \mathrm{~kg}$ of commercial organic fertilizer 'Petroganik' per seedbad $(10 \mathrm{~m} \times 5 \mathrm{~m})$ were applied. Irrigation was applied one week prior to transplanting. On water condition, flooding condition about $5 \mathrm{~cm}$ water depth was kept from transplanting until 15 days before harvest and then the field was drained.

\subsection{Sampling and Analysis}

Soil samples for initial analysis were collected at depths of 0-15 cm, air dried, grinded and sieved through $2 \mathrm{~mm}$ diameter (USDA No. 10) sieve. The soil available Si was extracted by $1 \mathrm{~mol} \mathrm{~L}^{-1}$ acetate buffer (pH 4.0) at a ratio of $1: 10$ for $5 \mathrm{~h}$ at $40^{\circ} \mathrm{C}$ with occasional shaking (Imaizumi \& Yoshida, 1958). Although Sumida (1991) reported that the acetate buffer method was not suitable for soils previously amended with silicate fertilizer, this was not a problem in Indonesia because no silicate fertilizer had been applied. The extracted Si content in the soil samples was determined using atomic absorption spectrophotometer (Z-5000; Hitachi, Tokyo, Japan). The soil pH was measured using the glass electrode method with a soil:water ratio of 1:2.5 (IITA, 1979; McLean, 1982). For determining soil exchangeable cation, soil samples were extracted with $1 M \mathrm{NH}_{4} \mathrm{OAc}$ at $\mathrm{pH} 7$ (Thomas, 1982) and measured by Inductive Coupled Plasma Spectroscopy (ICPE-9000 Shimadzu Co, Kyoto, Japan).

Stomata samples were collected with clear nail polish method (Radoglou \& Jarvis, 1990). Epidermal impression was prepared by coating the rice leaf surface with nail polish which was peeled off, once nail polish was dried, it was mounted onto a slide by a cello tape. The impression approach was used to determine the number of stomata. These impressions were observed by light microscopy (Olympus BX51) and number of stomatas were investigated in a field of $0.03 \mathrm{~mm}^{2}$ then we calculated the number of stomata in $\mathrm{mm}^{2}$ leaf area.

Blast disease infection was observed at 30,45 and 60 DAT for leaf blast and 75 and 90 DAT for neck blast. Sixteen plant samples were observed from each treatment for blast disease intensity. We observed leaf blast disease intensity using score value which was employed by IRRI System (1996). Score value for each symptom category of blast disease are 0: no lesions; 1 : small brown specks of pin-point size or large brown specks without speculating centre; 2 : small roundish to slightly elongated, necrotic grey spots about $1-2 \mathrm{~mm}$ in diameter with distinct brown margin; 3: same as score 2, but a significant number of lesions are on the upper leaves; 4: typical susceptible blast lesions $3 \mathrm{~mm}$ or longer, infecting less than $4 \%$ of leaf area; 5: typical blast lesion infecting 4$10 \%$ of leaf area; 6 : typical blast lesion infecting $11-25 \%$ of the leaf area; 7 : typical blast lesion infecting $26-50 \%$ of the leaf area; 8: typical blast lesion infecting $51-75 \%$ of the leaf area and 9: more than $75 \%$ leaf are affected. Moreover plant growth paramater consists of plant height and number of tillers also obeserved.

SPSS software for Windows version 20 was used for the statistical analysis. Values were expressed as means \pm SD. Student's t-test was performed at $\mathrm{p}<0.01$ to compare the effect of Si application. 


\section{Results}

\subsection{Effect of Silica Application on Leaf Blast}

The results of $\mathrm{Si}$ application on percentage of leaf blast infection are shown in Figure 1. Si application significantly $(\mathrm{p}<0.01)$ reduce leaf blast disease infection throughout the observation periods. The percentage were $0.6 \pm 0.2$ and $1.4 \pm 0.4$ at $30 \mathrm{DAT}, 0.4 \pm 0.3$ and $1.3 \pm 0.2$ at $45 \mathrm{DAT}$ and $0.3 \pm 0.2$ and $1.1 \pm 0.3$ at $60 \mathrm{DAT}$ for $\mathrm{Si}+$ and $\mathrm{Si}$ - treatments, respectively.

The Si application could also suppress the severity of leaf blast infection (Figure 1). Known that Si- had severer infection up to score 4 in 45 DAT and score 5 at 60 DAT. On the other hand, in $\mathrm{Si}+$ the leaf blast infection never reached score 4 and 5 at 45 and 60 DAT respectively. The difference in the leaf blast infection at the onset of the experiment, at $30 \mathrm{DAT}$ and the last observation at $60 \mathrm{DAT}$, showed that $\mathrm{Si}+$ had higher recovery rate on score 1 than $\mathrm{Si}-$ by $60 \%$ and $28 \%$ for $\mathrm{Si}+$ and $\mathrm{Si}$ - respectively. Moreover $\mathrm{Si}+$ also showed recovery rate on score $3(24 \%)$ but not in Si-.

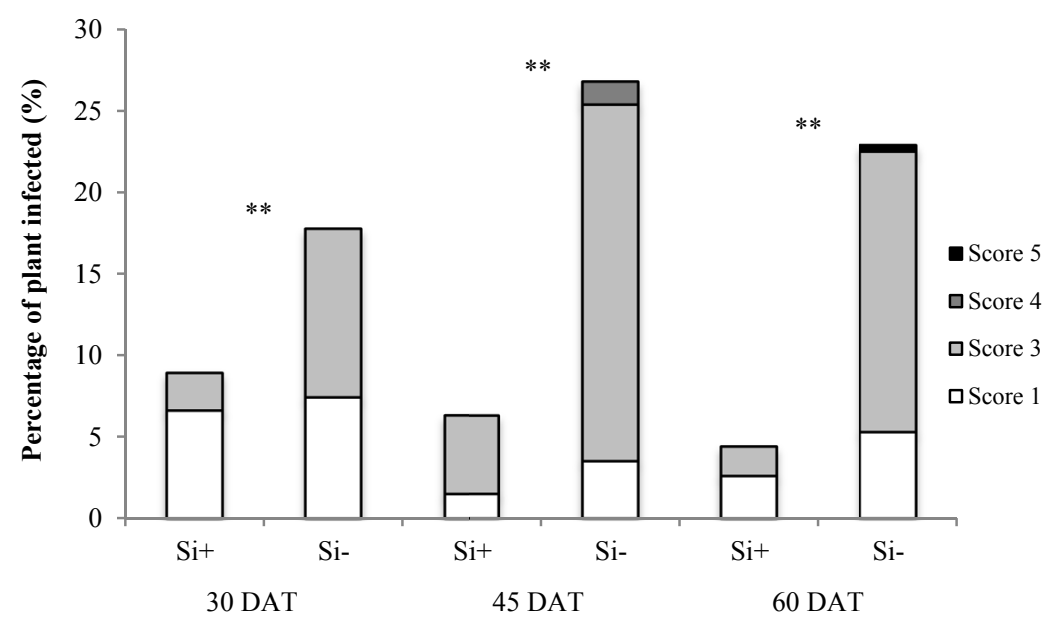

Figure 1. Percentage of plant infected by blast infection based on scoring value Note. **: Significant different at $\mathrm{p}<0.01$ between $\mathrm{Si}+$ and $\mathrm{Si}-$ at each observation stage.

The percentages of neck blast infection were $1.1 \pm 0.8 \%$ and $3.0 \pm 1.9 \%$ at 75 DAT and $10.2 \pm 3.9 \%$ and $16.9 \pm$ $7.9 \%$ at $90 \mathrm{DAT}$ for $\mathrm{Si}+$ and $\mathrm{Si}-$ treatments, respectively (Figure 2). Si application could also decrease significantly $(\mathrm{p}<0.05)$ neck blast infection by 63.1 and $39.7 \%$ at 75 and 90 DAT respectively.

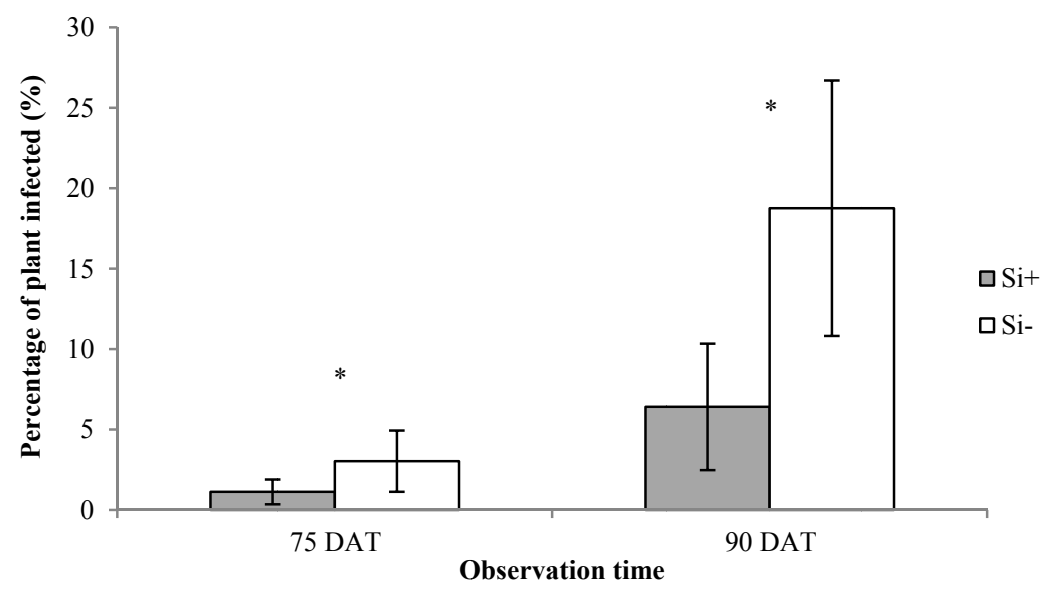

Figure 2. Percentage of neck blast infection at 75 and 90 DAT

Note. *: Significant different at $\mathrm{p}<0.05$. 


\subsection{Effect of Si Application on Rice Plant Growth and Yield}

The effect of Si application on plant growth and yield are shown on Table 2. Statistically there was no significant difference between $\mathrm{Si}+$ and $\mathrm{Si}$ - treatment on number of tillers, dry matter and yield. In yield even though not significant, but was slightly higher in $\mathrm{Si}+$ treatment when compare to $\mathrm{Si}-$ treatment.

Table 2. Effect of treatments on plant growth and yield of Ciherang variety

\begin{tabular}{lllll}
\hline \multirow{2}{*}{ Treatment } & \multicolumn{3}{c}{ Plant growth } & \multirow{2}{*}{ Yield (kg/plot) } \\
\cline { 2 - 4 } & Plant height $(\mathrm{cm})$ & Tillers & Dry matter $(\mathrm{g})$ & \\
\hline $\mathrm{Si}+$ & $92.1 \pm 1.2 \mathrm{~ns}$ & $17.4 \pm 1.5 \mathrm{~ns}$ & $59.2 \pm 6.7 \mathrm{~ns}$ & $4 \pm 0.2 \mathrm{~ns}$ \\
$\mathrm{Si}-$ & $92.1 \pm 1.1 \mathrm{~ns}$ & $16.7 \pm 1 \mathrm{~ns}$ & $55.4 \pm 10.9 \mathrm{~ns}$ & $3.9 \pm 0.3 \mathrm{~ns}$ \\
\hline
\end{tabular}

Note. ns: There was no significant difference $(\mathrm{p}<0.05)$ between $\mathrm{Si}+$ and $\mathrm{Si}-$.

\subsection{Effect of Si Application on Stomata Density}

Observations of stomata density showed that Si application significantly $(\mathrm{p}<0.01)$ increased stomata density at 7, 40 and 90 DAT for abaxial and 40 and 90 DAT for adaxial (Figure 3). The average of stomata density in abaxial leaf epidermis were $326 \pm 59$ and $276 \pm 76$ at 7 DAT, $526 \pm 60$ and $353 \pm 23$ at 40 DAT and $638 \pm 102$ and $455 \pm 111 \mathrm{~mm}^{-2}$ at $90 \mathrm{DAT}$ for $\mathrm{Si}+$ and Si- treatments, respectively. For adaxial leaf epidermis, it was $299 \pm$ 40 and $217 \pm 29$ at 7 DAT, $366 \pm 33$ and $265 \pm 28$ at 40 DAT and $342 \pm 54$ and $247 \pm 20 \mathrm{~mm}^{-2}$ at 90 DAT for Si+ and Si- treatments, respectively. Stomata density of Ciherangrice rice variety was higher on abaxial surface than adaxial surface of which coincide with what is obtainable with other rice varieties in previous study (Willmer \& Fricker, 1996a; Gao et al., 2006).



Figure 3. Stomata density of Ciherang variety

Note. **: Significant different at $\mathrm{p}<0.01$.

\subsection{Effect of Si Application on Stomata Length}

The results of stomata length was listed on Table 3. The data showed that Si application on stomata length were not significant on both in abaxial and adaxial surface. Moreover, the results from three observations $(7,40$ and 60 DAT) showed that the stomata length tends to decrease slightly as the stomata density increases in both treatments. 
Table 3. Effect of treatments on stomata length $(\mathrm{mm})$

\begin{tabular}{|c|c|c|c|}
\hline \multirow{2}{*}{ Treatment } & \multicolumn{3}{|c|}{ Stomata length $\left(\times 10^{-9} \mathrm{~mm}\right)$} \\
\hline & 7 DAT & 40 DAT & 90 DAT \\
\hline & Abaxial & & \\
\hline $\mathrm{Si}+$ & $16 \pm 2.2 \mathrm{a}$ & $14 \pm 1.4 \mathrm{a}$ & $12 \pm 0.6 \mathrm{a}$ \\
\hline Si- & $15 \pm 2.2 \mathrm{a}$ & $14 \pm 0.9 \mathrm{a}$ & $11 \pm 0.7 \mathrm{a}$ \\
\hline & Adaxial & & \\
\hline $\mathrm{Si}+$ & $15 \pm 0.9 \mathrm{a}$ & $14 \pm 0.5 \mathrm{a}$ & $13 \pm 0.4 \mathrm{a}$ \\
\hline Si- & $15 \pm 0.9 \mathrm{a}$ & $14 \pm 0.1 \mathrm{a}$ & $13 \pm 0.7 \mathrm{a}$ \\
\hline
\end{tabular}

Note. Means followed by the same latter in the colum do not differ significantly at $\mathrm{p}<0.05$.

\section{Discussion}

The result showed that $\mathrm{Si}$ application could suppress the severity of leaf blast infection (Figure 1). This indicates that $\mathrm{Si}$ application reduces the expansion of lesion as score 4 and 5 only appeared on $\mathrm{Si}$ - treatment. This might be as a result of physical barrier created by $\mathrm{Si}$ in the cuticle layer to reduce lesion, through organo silicon compound that accumulated in the wall of epidermal cell (Volk et al., 1958; Rodrigues et al., 2001).

Si application clearly gave the positive effect on decreasing leaf and neck blast infection on Ciherang variety as reported in other rice varieties in different countries such as in Japan, Brazil and Thailand (Seebold, 1988; Prabhu et al., 2001; Hayasaka et al., 2005; Wattanapayapkul et al., 2011). The specific mechanisms responsible for Si ability to increase plant resistant to blast disease are not fully understood. Related to our result, we believe that Si deposited on the tissue surface acts as a physical barrier by thickening the Si layer in the cuticle known as Si-cuticle double layer which could decrease the number of blast lessions on leaf blades and also improved stomata control (Yoshida, 1965; Datnoff \& Rodrigues, 2005). Also Si-cuticle double layer probably limits hypa penetration and invasion by acting as a physical barrier (Kim et al., 2002).

The usage of fungicides is the most common method to control blast disease in Indonesia beacause it is easy to access and to apply for local farmers. Yuliani and Maryana (2014) stated that fungicide application could suppres leaf and neck blast infection by $40-60 \%$ and $60-80 \%$ respectively. However when the farmers delay the planting season, fungicide application will be ineffective on suppressing blast disease. Delaying planting season cause the heading stage to concide with the period of high dew which is favorable for blast disease infestation (Santoso \& Nasution, 2009). In addition, the study site had expeienced severe blast incidence for the past five years due to continuous use of the fungicides on rice cultivar against Pyricularia grisea. The fungus over time tends to shift inpopulation as it become resistance to fungicides, making the rice cultivar susceptible to the attack (Tangdiabang \& Pakki, 2006). On this regard Si application could be an effective and sustainable strategy to control blast disease.

The soil initially contained available $\mathrm{Si}$ of $427 \mathrm{mg} \cdot \mathrm{kg}^{-1}$ which was 4.5 times higher than the criterion of Si deficient level by Dobermann and Fairhurst (2000). Nevertheless, Si application could give significant effect on reducing leaf and neck blast disease infection in this site. This agreed with previous studies, Si application in soil that had available Si level higher than the critical level, about $437-581 \mathrm{mg} \cdot \mathrm{kg}^{-1}$ still gave significant effect on increasing the yield (IRRI, 1964; Su et al., 1983) and decreasing blast disease severity (Wattanapayapkul et al., 2011) without any toxic side effects as Ma et al. (2001) reported. In the present study also, we have not observed any negative effect of Si application although it resulted in no significant effect on the yield but reduces blast disease infection.

Generally previous studies reported that addition of Si could increase the rice yield due to the balanced nutrient management that includes Si fertilization (Savant et al., 1997; Epstein, 1999). However, our result did not show significant difference. This might be due to application period of Si fertilizer. The most effective period of Si application for increasing yields was reproductive stage in which Si uptake and dry matter production are most vigorous (Savant et al., 1997). In the present study, we applied Si fertilizer before transplanting in order to improve plant resistance to blast disease from early growth stage. As rice plant takes up $\mathrm{Si}$, it gradually accumulates in the leaf and creates Si cuticle double layer which can act as physical barrier against to blast disease infection (Ma, 2004). Although the yield was not increased by Si application, in this present study Si application has potential to improve the yield through supressing blast disease especially neck blast since it often causes severe yield losses due to the reducing the number of filled grains. 
In relation to $\mathrm{Si}$ application on stomatal behaviour, i.e. stomata conductance has been focused on while less attention has been paid to stomatal formation, observed as morphology and density. Some of previous studies presumed that Si plays a role in decreasing the transpiration rate by changing the stomatal movement rather than affecting its morphology and density (Gao et al., 2006; Zargar \& Agnihotri, 2013). In contrast, Dias et al. (2014) showed similiar result with the present study which stated that there is indication that addition of Si as sodium silicate promoted the development of higher stomata density.

Salisbury (1927) reported that stomatal density is determined by stomatal initiation during ontogenesis and by epidermal cell expansion at a later leaf growth stage. In this research, it was observed that stomata density increases at the leaf growth stage in both $\mathrm{Si}+$ and $\mathrm{Si}-$ treatments. Stomata density in abaxial surface increased from 7 to $40 \mathrm{DAT}$ by 61 and $28 \%$ in $\mathrm{Si}+$ and $\mathrm{Si}$ - treatment respectively. The increase in stomata density at 40 DAT to $90 \mathrm{DAT}$ were 21 and $29 \%$ for $\mathrm{Si}+$ and $\mathrm{Si}-$ treatment respectively. Meanwhile in adaxial surface, the increase only occured from 7 DAT to 40 DAT and it was relatively small, about $22 \%$ and was the same for $\mathrm{Si}+$ and Si-. Although it is not clearly understood how stomatal density is controlled during leaf growth (Bergmann, 2004).

The increament of stomata density on $\mathrm{Si}+$ treatment might be related to the $\mathrm{Si}$ deposition that caused the cuticle layer to become thicker. As Si is deposited beneath cuticle layer and forming a fine cuticle-Si double layer, it acts as physical barrier that protects against various environmental stresses (Shepherd \& Griffiths, 2006). Alternatively cuticle layer profile may alter permeability to water, $\mathrm{CO}_{2}$ and other signalling compound that influences stomata development. $\mathrm{CO}_{2}$ and light levels have also been known to elicit changes in stomata numbers (Woodward, 1987). In many species, the trend is for a reduction in stomata density and index with increases in $\mathrm{CO}_{2}$ level. $\mathrm{Si}$ in leaf epidermis might prevent $\mathrm{CO}_{2}$ diffusion through increase in stomata density. On the orther hand, Soares et al. (2012) stated that Si treatments reduced the development of the stomata characteristic such as stomata density and also stated that in the absense of $\mathrm{Si}$, the stomata might be more capable of capturing $\mathrm{CO}_{2}$ and preventing water loss.

Stomata are cell complexes specialized for gas exchange between plants and their environments. Stomatal movement, density, and distribution determine plant water and $\mathrm{CO}_{2}$ exchange, including photosynthesis and transpiration. Stomatal density affects gas exchange, transpiration, conductance, and instantaneous water use efficiency (Woodward \& Bazzaz, 1988).

In relation to yield, some previous study stated that the improvement on morphological characteristics of stomata such as stomata density could improve the yield (Jones, 1992; Ishimaru et al., 2001). However, in the present study the result of the yield showed not significant different although $\mathrm{Si}+$ was significantly higher than $\mathrm{Si}$ - in stomata density. This result showed that stomata density indirectly regulates photosynthesis rate and transpiration rate which affect yield improvement. This present result was in agreement with Ohsumi et al. (2007), who stated that improvement of the morphological characteristic of stomata on the yield is not evident because consistent relationship have not been proven between morphological characteristic of stomata with stomatal conductance in correlated with photosynthesis. This explained why with higher stomata density in $\mathrm{Si}+$ treatment showed no significant different on yield compared to Si- treatment. However, the potential of Si application on improvement of plant growth and yield through blast disease suppression and increasing stomata density is visible in the present study.

From the observation on stomata at 40 and 90 DAT in abaxial surface, we found that for $\mathrm{Si}+$ treatment the pattern of stomata is arranged in single file in low phyllotaxis leaves with two adjacent stomata rows, meanwhile for Si- treatment the pattern is arranged only in single file (Figure 4). This appearence of adjancent stomata rows in $\mathrm{Si}+$ treatment might be the reason for the increase in stomata density per unit area which was observed in abaxial surface of the flag leaves in $\mathrm{Si}+$ treatment compared to $\mathrm{Si}$ - treatment. Stomata were usually arranged in a single file in low phylotaxis leaves and two or more adjacent stomatal rows (Luo et al., 2012) which was observed in $\mathrm{Si}+$ treatment. 

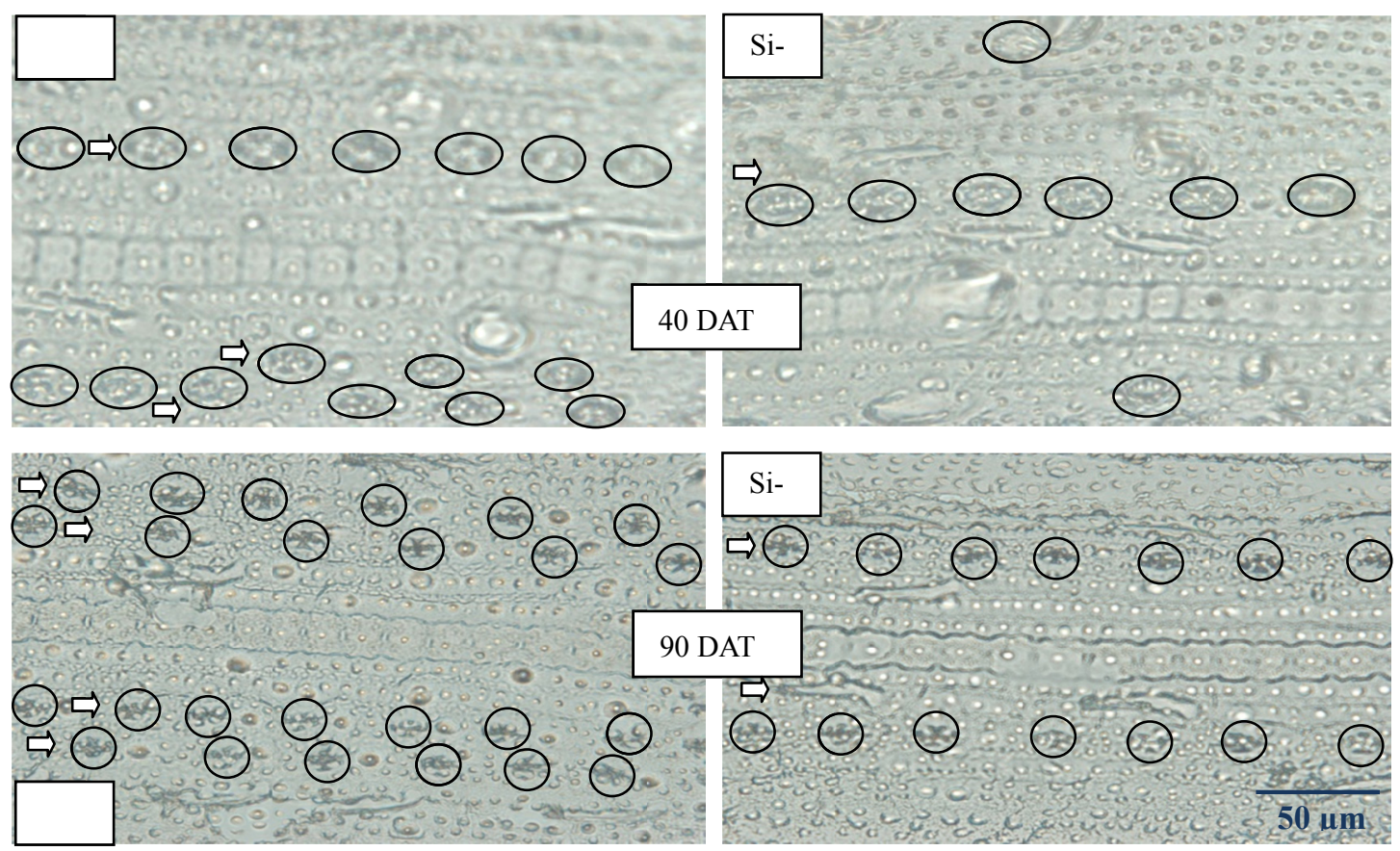

Figure 4. The difference of stomata pattern on $\mathrm{Si}+$ and $\mathrm{Si}$ - at $40 \mathrm{DAT}$ (upper) and $90 \mathrm{DAT}$ (lower) with area observation $0.03 \mathrm{~mm}^{2}$

Deposition of $\mathrm{Si}$ in the cell walls had been considered a common phenomenon in many plants, especially in graminaceous like rice (Parry \& Winslow, 1977). Si accumulates in the lower epidermis around the stomata, including guard cells of blueberry (Vaccinum corymbosus L. cv) 'Bluecrop' as found by Morikawa and Saigusa (2004). There was no report about this phenomenon in rice plant which could prove whether Si deposition around stomata will improve or change the stomata density. Previous research only mentioned that stomatal density is affected by environmental factors and its genetic control is evident (Hetherington \& Woodward, 2003).

Moreover, the results from three observations (7, 40 and 60 DAT) showed that the stomata length tends to decrease slightly as the stomata density increases in both treatments. Beerling and Woodward (1997) stated that plants with high stomatal density tend to have smaller size of stomata. This condition was also observed in the experiment with plant growth increasing with increase in stomata density while the stomata length decreases.

\section{Conclusion}

These results demonstrate that $\mathrm{Si}$ application showed positive effect on supressing leaf and neck blast disease attack on Ciherang rice variety. Although the study site had soil available Si above critical level proposed by Sumida (1992), Si application gave significant effect. Si application also significantly increases stomata density. The results confirmed that $\mathrm{Si}$ application have potential to improve rice growth and yield through the improvement of resistance to blast infection and increment of stomata density in Indonesia although they did not result in the yield increment in the present study. Regarding to blast disease, Si application could be an alternative strategy instead of fungicide application that has been commonly practiced which has resulted to the problem of fungicide tolerant over blast disease. Since Si application has not been applied yet in Indonesia, this study is a good reference for Si apllication in Indonesian rice cultivation. Due to this issue, Si fertilizer has not been produced yet in Indonesia. Therefore, it is necessary to find cost effective local source of Si fertilizer and to produce it. Furthermore, related to the effect $\mathrm{Si}$ application on stomata density further study needs to be conducted to find out the mechanism on it.

\section{Acknowledgements}

This work was supported by JSPS KAKENHI Grant Number 24405047, 25257405.

\section{References}

Beerling, D. J., \& Woodward, F. I. (1997). Changes in land plant function over the phanerozoic: Reconstructions based on the fossil record. Bot. J. Linn. Soc., 124, 137-153. http://dx.doi.org/10.1111/j.1095-8339.1997. tb01787.x 
Bergmann, D. C. (2004). Integrating signals in stomatal development. Current Opinion in Plant Biology, 7 , 26-32. http://dx.doi.org/10.1016/j.pbi.2003.10.001

Darmawan, Kyuma, K., Saleh, A., Subagjo, H., Masunaga, T., \& Wakatsuki, T. (2006). Effect of long-term intensive rice cultivation on the available silica content of sawah soils: Java Island, Indonesia. Soil Sci. Plant Nutr., 52, 745-753. http://dx.doi.org/10.1111/j.1747-0765.2006.00089.x

Datnoff, L. E., \& Rodrigues, F. A. (2005). The role of silicon in suppressing rice diseases. APSnet Features. http://dx.doi.org/170.1094/APSnetFeature-2005-0205

Dias, G. M. G., Soares, J. D. R., Pasqual, M., Silva, R. A. L., Rodrigues, L. C. A., Pereire, F. J., \& Castro, E. M. (2014). Photosynthesis and leaf anatomy of Anthurium cv. Rubi plantlets cultured in vitro under different silicon (Si) concentrations. AJCS, 8(8), 1160-1167.

Dobermann, A., \& Fairhurst, T. (2000). Rice: Nutrient disorders and nutrient management. Singapore and Los Banõs: Potash \& Phosphate Institute (PPI), Potash \& Phosphate Inst. of Canada (PPIC), and Int. Rice Res. Inst. (IRRI), Los Banõs, Philippine.

Effendi, A. C., Kusnama, \& Hermanto, B. (1998). Geological map of the the Bogor quadrangle, Jawa. Geological Research and Development Centre. Bandung, Indonesia.

Epstein, E. (1994). The anomaly of silicon in plant biology. Proceedings of the National Academy of Sciences of the United States of America, 91, 11-17. http://dx.doi.org/10.1073/pnas.91.1.11

Epstein, E. (1999). Silicon. Annu. Rev. Plant. Physiol. Plant. Mol. Biol., 50, 641-664. http://dx.doi.org/10.1146/annurev.arplant.50.1.641

FAO (Food and Agricultural Organization). (2015). FAOSTAT. FAO, Rome, Italy. Retrieved September 2, 2015, from http://faostat.fao.org

Faure, G. (1991). Principles and applications of the inorganic chemistry (p. 626). Macmillan Publishing Company, United States of America.

Gao, X., Zou, C., Wang, L., \& Zhang, F. (2006). Silicon decreases transpiration rate and conductance from stomata of maize plants. Journal of Plant Nutrition, 29, 1637-1647. http://dx.doi.org/10.1080/01904160600851494

Hasanuddin, A. (2004). Pengendalian hama dan penyakit padi: Upaya tiada henti. Inovasi Pertanian Tanaman Pangan. Pusdlitbangtan Bogor.

Hayasaka, T., Fujii, H., \& Namai, T. (2005). Silicon content in rice seedlings to protect rice blast fungus at the nursery stage. Journal of General Plant Pathology, 71(3), 169-173. http://dx.doi.org/10.1007/s10327-005-0182-7

Hetherington, A. M., \& Woodward, F. I. (2003). The role of stomata in sensing and driving environmental change. Nature, 424, 901-908. http://dx.doi.org/10.1038/nature01843

Husnain, Aflizar, Darmawan, \& Masunaga, T. (2011). Study on soil silicon status in Indonesia. Proceeding of the $5^{\text {th }}$ International Conference on Silicon in Agriculture, September 13-18, 2011, Beijing.

Husnain, Wakatsuki, T., Setyorini, D., Hermansah, Sato, K., \& Masunaga, T. (2008). Silica availability in soils and river water in two watersheds on Java Island, Indonesia. Soil Sci. Plant Nutr., 54, 916-927. http://dx.doi.org/10.1111/j.1747-0765.2008.00313.x

Husnain. (2009). Nutrient dynamics in watersheds and lowland sawah in Java island in relation to the sustainability of sawah farming systems in Indonesia (Unpublished doctoral dissertation, The United Graduate School of Agricultural Sciences, Tottori University, Japan).

IITA. (1979). Selections methods for soil and plant analyses. Manual Series No. 1. Ibadan, Nigeria.

Iller, R. K. (1979). The chemistry of silica: Solubility, polymerization, colloid and surface properties and biochemistry. New York, NY: John Wiley and Sons.

Imaizumi, K., \& Yoshida, S. (1958). Edaphological studies on silicon supplying power of paddy field. Bull. Natl. Inst. Agric. Sci., B8, 261-304.

Ingri, N. (1978). Aqueous silicic acids, silicates and silicate complexes. In G. Bendz \& J. Lindquist (Eds.), Biochemistry of silicon and related problems (pp. 3-52). Plenum, New York. http://dx.doi.org/10.1007/978-1-4613-4018-8_1 
International Rice Research Institute (IRRI). (1964). Annual report 1963. Los Banõs, Laguna, Philippines.

International Rice Research Institute (IRRI). (1996). Standard evaluation system for rice (4th ed.). Los Banõs, Laguna, Philippines: International Rice Research Institute (IRRI).

Ishimaru, K., Shirota, K., Higa, M., \& Kawamitsu, Y. (2001). Identification of quantitative loci for adaxial and abaxial frequencies in Oryza sativa. Plant Physiol. Biochem., 39, 173-177. http://dx.doi.org/10.1016/S0981-9428(00)01232-8

Jones, H. G. (1992). Plants and microclimate (2nd ed). Cambridge : Cambridge University press.

Kawaguchi, K. (1966). Tropical paddy soils. Jpn. Agric. Res., Q. 1, 7-11.

Kawaguchi, K., \& Kyuma, K. (1977). Paddy soils in tropical Asia, their material nature and fertility. Honolulu: Univ. Press of Hawaii.

Kim, S. G., Kim, K. W., Park, E. W., \& Choi, D. (2002). Silicon-induced cell wall fortification of rice leaves: a possible cellular mechanism of enhanced host resistance to blast. Phytopathology, 92(10), 1045-1103. http://dx.doi.org/10.1094/PHYTO.2002.92.10.1095

Klein, C., \& Hurlbut, C. S. Jr. (1985). Manual of Mineralogy (20th ed.). Canada: John Wiley and Sons.

Korndorfer, G. H., \& Lepsch, I. (2001). Effect of silicon on plant growth and crop yield. In L. E. Datnoff \& G. H. Korndorfer (Eds.), Studies in plant science (pp. 133-147). Amsterdam : Elsevier.

Le Maitre, R. W. (2005). Igneous rocks: A classification and glossary of terms. Recommendations of the International Union of Geological Sciences Subcommission on the Systematics of Igneous Rocks (2nd ed.). Cambridge: Cambridge University Press.

Luo, L., Zhuo, W. Q., Liu, P., Li, C. X., \& Hou, S. W. (2012). The development of stomata and other epidermal cells on the rice leaves. Biologia Plantarum, 56(3), 521-527. http://dx.doi.org/10.1007/s10535-012-0045-y

Ma, J. F. (2004). Role of silicon in enhancing the resistance of plants to biotic and abiotic stresses. Soil Sci. Plant Nutr., 50(1), 11-18. http://dx.doi.org/10.1080/00380768.2004.10408447

Ma, J. F., \& Takahashi, E. (2002). Soil, fertilizer, and plant silicon research in Japan. Amsterdam: Elsevier.

Ma, J. F., Miyake, Y., \& Takahashi, E. (2001). Silicon as a beneficial element for crop plants. In L. E. Datnoff, G. H. Snyder \& G. H. Korndorfer (Eds.), Silicon in agricultura (pp. 17-39). Amsterdam: Elsevier. http://dx.doi.org/10.1016/S0928-3420(01)80006-9

Ma, J. F., Tamai, K., Yamaji, N., Mitani, N., Konishi, S., Katsuhara, M., ... Yano, M. (2006). A silicon transporter in rice. Nature, 440, 688-691. http://dx.doi.org/10.1038/nature04590

Matichenkov, V. V., \& Calvert, D. V. (2002). Silicon as a beneficial element for sugarcane. J. Am. Soc. Sugarcane Tech., 22, 21-30.

McLean, E. O. (1982). Soils pH and lime requirement. In A. L. Page, E. Baker, \& R. Ellis Jr. et al. (Eds.), Methods of Soil Analysis (No. 9, Part 2, pp. 199-209). Madison, Wisconsin: SSSA.

Ministry of Agriculture of Republic Indonesia. (2015). Harvested area, yield and productivity of rice. Basis data of agricultura. Retrieved September 2, 2015, from http://aplikasi.pertanian.go.id/bdsp/index.asp

Miyake, Y. (1993). Silica in soils and plants. Sci. Rep. Faculty of Okayama Univ., 81, 61-79.

Morikawa, C. K., \& Saigusa, M. (2004). Mineral composition and accumulation of silicon in tissues of blueberry (Vaccinum corymbosus cv. Bluecrop) cuttings. Plant and Soil, 258, 1-8. http://dx.doi.org/10.1023/B:PLSO.0000016489.69114.55

Ohsumi, A., Kanemura, T., Homma, K., Horie, T., \& Shiraiwa, T. (2007). Genotype variation of stomatal conductance in relation to stomatal density and length in rice (Oryza sativa L). Plant Prod Sci, 10(3), 322-328. http://doi.org/10.1626/pps.10.322

Parry, D. W., \& Winslow, A. (1977). Electron-probe microanalysis of silicon accumulation in the leaves and tendrils of Pisum sativum (L.) following root severance. Ann. Bot., 41, 275-278.

Prabhu, A. S., Filho, M. P. B., Datnoff, L. E., \&Snyder, G. H. (2001). Silicon from rice disease control perspective in Brazil. In L. E. Datnoff, G. H. Snyder, \& G. H. Korndorfer (Eds.), Silicon in agricultura (pp. 293-311). Amsterdam: Elsevier. http://dx.doi.org/10.1016/S0928-3420(01)80022-7

Radoglou, K. M., \& Jarvis, P. G. (1990). Effects of $\mathrm{CO}_{2}$ enrichment on four polar clones. Leaf surface properties. Ann. Bot., 65, 627-632. 
Rodrigues, F. A., Datnoff, L. E., Korndorfer, G. H., Seebold, K. W., \& Rush, M. C. (2001). Effect of silicon and host resistance on sheath blight development in rice. Plant Dis., 85, 827-832. http://dx.doi.org/10.1094/PDIS.2001.85.8.827

Roy, R. N., Misra, R. V., Lesschen, J. P., \& Smaling, E. M. (2003). Assessment of soil nutrient balance. Approaches and methodologies. FAO Fertilizer and Plant Nutrition Bulletin 14 (p. 101). Food and Agriculture Organization of the United Nations. Retrieved September 3, 2015, from http://www.fao.org/docrep/006/y5066e/y5066e00.htm

Salisbury, E. J. (1927). On the causes and ecological significance of stomatal frequency with special reference to the woodland flora. Philosophical Transactions of the Royal Society of London Biological Sciences, 216, 1-65. http://dx.doi.org/10.1098/rstb.1928.0001

Santoso, \& Nasution, A. (2009). Pengendalian penyakit blas dan penyakit cendawan lainnya. Dalam Inovasi Teknologi Produksi Padi. Buku 2. Balai Besar Penelitian Tanaman Padi. Badan Penelitian dan Pengembangan Pertanian (pp. 531-563).

Savant, N. K., Snyder, G. H., \& Datnoff, L. E. (1997). Silicon managements and sustainable rice production. Advances in Agronomy (Vol. 58). Academic Press. http://dx.doi.org/10.1016/S0065-2113(08)60255-2

Seebold, K. W. (1988). The influence of silicon fertilization on the development and control of blast caused by Magnoporthe grisea (Hebert) Barr. in upland rice (Unpublished doctoral dissertation, University of Florida, Gainesville).

Shepherd, T., \& Griffiths, W. (2006). The effects of stress on plant cuticular waxes. New Phytologist, 171, 469-499. http://dx.doi.org/10.1111/j.1469-8137.2006.01826.x

Soares, J. D. R., Pasqual, M., Araujo, A. G., Castro, E. M., Pereira, F. J., \& Braga, F. T. (2012). Leaf anatomy of orchids micropropagated with different silicon concentration. Acta Scientiarum. Agronomy, 34(4),413-421. http://dx.doi.org/10.4025/actasciagron.v34i4.15062

$\mathrm{Su}$, N. R., Shen, L., \& Lee, T. S. (1983). Availability of the native soil and residual fertilizer silica to rice plants. J. Agric. Assoc. China, 122, 46-62.

Sumida, H. (1991). Characteristics of silica dissolution and adsorption in paddy soils: Application to soil test for available silica. Jap. J. Soil Sci. Plant Nutr., 62, 378-385.

Sumida, H. (1992). Silicon supplying capacity of paddy soils and characteristics of silicon uptake by rice plants in cool regions in Japan. Bull. Tohoku. Agric. Exp. Stn., 85, 1-46.

Tangdiabang, J., \& Pakki, S. (2006). Penyakit blast (Pyriculariagrisea) dan strategi pengendaliannya pada tanaman padi. Pusat Penelitian Tanaman Pangan. Departemen Pertanian, 7, 241-245.

Thomas, G. W. (1982). Exchangeable cations. In A. L. Page (Ed.), Methods of soil analysis, Part 2 Chemical and microbiological properties (2nd ed., Agronomy 9, pp. 159-165).

Volk, R. J., Kahn, R. P., \& Weintraub, R. L. (1958). Silicon content of the rice plant as a factor in influencing its resistance to infection by the rice blast fungus Piricularia oryzae. Phytopathology, 48, 179-184. http://dx.doi.org/10.1590/S0100-41582005000500001

Wakatsuki, T., Shimura, Y., Otoo, E., \& Olaniyan, G. O. (1998). African-based sawah system for the integrated watershed management of small inland valleys of West Africa. FAO Water Report, 17, 56-79.

Wattanapayapkul, W., Polthanee, A., Siri, B., Bhadalung, N. N., \& Promkhambut, A. (2011). Effects of silicon in suppressing blast disease and increasing grain yield of organic rice in Northeast Thailand. Asian Journal of Plant Pathology, 5, 134-145. http://dx.doi.org/10.3923/ajppaj.2011.134.145

Wibowo, B. S. (2011). Sebaran dan perkembangan OPT padi. Prosiding Seminar Nasional Penyakit Tungro, Makassar, Indonesia.

Willmer, C., \& Fricker, M. (1996a). The distribution of stomata. In C. Willmer \& M. Fricker (Eds.), Stomata (pp. 18-19). Chapman \& Hall, London. http://dx.doi.org/10.1007/978-94-011-0579-8_2

Woodward, F. I. (1987). Stomatal numbers are sensitive to increases in $\mathrm{CO}_{2}$ from pre-industrial levels. Nature, 32, 617-618. http://dx.doi.org/10.1038/327617a0

Woodward, F. I., \& Bazzaz, F. A. (1988). The responses of stomatal density to $\mathrm{CO}_{2}$ partial-pressure. Journal of Experimental Botany, 39, 1771-1781. http://dx.doi.org/10.1093/jxb/39.12.1771

Yoshida, S. (1965). Chemical aspects of the role of silicon in physiology of the rice plant. Bull Natl Inst Agric, 
Sci Series B., 15, 1-58.

Yuliani, D., \& Maryana, Y. E. (2014). Integrasi teknologi pengendalian penyakit blast pada tanaman padi di lahan sub optimal. Prosiding Seminar Nasional Lahan Suboptimal 2014, Palembang September 26-27, 2014.

Zargar, S. M., \& Agnihotri, A. (2013). Impact of silicon on various agro-morphological and physiological parameters in maize and revealing its role in enhancing water stress tolerance. J. Food Agric., 25(2), 138-141. http://dx.doi.org/10.9755/ejfa.v25i2.10581

\section{Copyrights}

Copyright for this article is retained by the author(s), with first publication rights granted to the journal.

This is an open-access article distributed under the terms and conditions of the Creative Commons Attribution license (http://creativecommons.org/licenses/by/3.0/). 